\title{
Southern African responses to the COVID-19 pandemic: A study of Botswana and South Africa
}

\begin{tabular}{|c|c|}
\hline \multicolumn{2}{|c|}{$\begin{array}{l}\text { Authors: } \\
\text { Tyanai Masiya }^{1} \text { (D) } \\
\text { David Mandiyanike }^{2} \text { (c) } \\
\text { Dintle Molosiwa }^{3} \text { (]) } \\
\text { Adrino Mazenda }^{1} \text { (]) }\end{array}$} \\
\hline \multicolumn{2}{|c|}{$\begin{array}{l}\text { Affiliations: } \\
{ }^{1} \text { School of Public Management } \\
\text { and Administration, Faculty of } \\
\text { Economic and Management } \\
\text { Sciences, University of } \\
\text { Pretoria, Pretoria, South Africa }\end{array}$} \\
\hline \multicolumn{2}{|c|}{$\begin{array}{l}{ }^{2} \text { Department of Politics and } \\
\text { Administration, University } \\
\text { of Botswana, Gabarone, } \\
\text { Botswana }\end{array}$} \\
\hline \multicolumn{2}{|c|}{$\begin{array}{l}{ }^{3} \text { Department of Family } \\
\text { Medicine and Public Health, } \\
\text { Faculty of Medicine, } \\
\text { University of Botswana, } \\
\text { Gaborone, Botswana }\end{array}$} \\
\hline \multicolumn{2}{|c|}{$\begin{array}{l}\text { Corresponding author: } \\
\text { Tyanai Masiya, } \\
\text { tyanai.masiya@up.ac.za }\end{array}$} \\
\hline \multicolumn{2}{|c|}{$\begin{array}{l}\text { Received: } 14 \text { Sept. } 2020 \\
\text { Accepted: } 26 \text { Feb. } 2021 \\
\text { Published: } 04 \text { May } 2021\end{array}$} \\
\hline \multicolumn{2}{|c|}{$\begin{array}{l}\text { How to cite this article: } \\
\text { Masiya, T., Mandiyanike, D., } \\
\text { Molosiwa, D. \& Mazenda, A., } \\
\text { 2021, 'Southern African } \\
\text { responses to the COVID-19 } \\
\text { pandemic: A study of } \\
\text { Botswana and South Africa', } \\
\text { Africa's Public Service } \\
\text { Delivery and Performance } \\
\text { Review 9(1), a497. https:// } \\
\text { doi.org/10.4102/apsdpr. } \\
\text { v9i1.497 }\end{array}$} \\
\hline \multicolumn{2}{|c|}{$\begin{array}{l}\text { Copyright: } \\
\text { (c) 2021. The Authors. } \\
\text { Licensee: AOSIS. This work } \\
\text { is licensed under the } \\
\text { Creative Commons } \\
\text { Attribution License. }\end{array}$} \\
\hline \multicolumn{2}{|l|}{ Read online: } \\
\hline 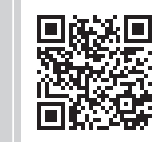 & $\begin{array}{l}\text { Scan this QR } \\
\text { code with your } \\
\text { smart phone or } \\
\text { mobile device } \\
\text { to read online. }\end{array}$ \\
\hline
\end{tabular}

Background: Southern African countries adopted diverse responses to the challenge posed by the COVID-19 pandemic outbreak, which manifested itself as both a health and economic disaster.

Aim: Using a case study approach of two South African countries, namely Botswana and South Africa, the article assessed their response measures to the COVID-19 pandemic.

Setting: Southern African countries applied 'domesticated' forms of responses thus, there has been no one-size-fits-all approach to managing the pandemic.

Methods: The study adopted a qualitative approach. Two case studies namely Botswana and South Africa were used. Documentary evidence was drawn from these case studies.

Results: To ensure that Southern African countries and indeed the world in general navigate the challenges posed by the COVID-19 pandemic, the World Health Organization (WHO) developed operational planning guidelines that had sought to balance the demands of responding effectively to COVID-19 and the need to serve economies from collapse. However, an analysis of the programmes of responses in South African countries such as Botswana showed the 'domestication' of the guidelines. Nevertheless, the guidelines, although having met with criticism in some cases had significantly contributed to the effective management of COVID-19 health and economic effects.

Conclusion: The COVID-19 pandemic required the state and its institutions to exercise effective leadership and unified action. In South African countries such as Botswana and South Africa, this pandemic showed the importance of governments in shaping the effectiveness of national responses, strategies and approaches in tackling the crisis.

Keywords: Botswana; COVID-19; economic measures; health measures; South Africa; guidelines; policy response; socio-economic crisis.

\section{Introduction}

The coronavirus disease 2019 (COVID-19), detected in 188 countries of the world in the first month of 2020, spreads rapidly with more than 6.9 million confirmed cases as of June 2020. It manifested itself as both a health and economic disaster. The virus has not spared Southern Africa. In response, affected countries used health prevention and control measures in parallel with broad economic safety nets in order to create sustainable health outcomes backed by stable economies. This is because, without intervention in the economy, most COVID-19 prevention and control measures seem likely to result in economic crises. The United Nations's (UN's) Framework for the Immediate Socio-Economic Response (2020:3) to the COVID-19 crisis warns that 'The COVID-19 pandemic is far more than a health crisis: it is affecting societies and economies at their core'. It can be noticed that although the impact of the pandemic will vary from country to country, it will most likely increase health challenges, poverty and inequalities. In view of Sothern Africa's vulnerable health and economic systems, it is important to study the measures that governments in the region have taken to mitigate the spread of the disease and at the same time ensuring the pursuit of effective economic safety nets given the potentially devastating impact of the pandemic on the two sectors.

In studying Southern African responses to COVID-19, this research analyses the management of health and economic priorities in the control and prevention of the COVID-19 in Botswana and South Africa to understand the consequences of the actions and draw lessons for future management of similar pandemics. 
The study also seeks to establish the extent to which Southern African governments such as the two case study countries can respond to and formulate strategies that are commensurate with their challenges in the health sector that at the same time have apparent consequences for the economy as the case is with COVID-19.

Botswana and South Africa have been selected because they provide contrasting Southern African cases in many respects. Whilst both are open democracies and went on lockdown and implemented similar health and prevention measures, their health and economic circumstances in the context of COVID-19 are different and provide us with different contexts. Furthermore, South Africa has a huge population of approximately 58.8 million (StatsSA 2020) and Botswana's population is 2024904 (Botswana Statistics 2015:3). The spread of COVID-19 in South Africa has been massive, standing at a pick of 639362 cases and 15000 deaths by the beginning of September 2020 (National Institute for Communicable Diseases 2020). Botswana remains amongst the least affected African countries with 2252 cases and only 10 deaths (Worldometer 2020). In that regard, the two cases give a fair representative context of studying responses in both most-affected and least-affected Southern African countries.

The pandemic requires the state and its institutions to exercise effective leadership and unified action. This pandemic, like the bird flu in June 2002 that induced a global pandemic and the worldwide contamination by the Severe Acute Respiratory Syndrome (SARS) virus, showed the importance of governments' crisis management capabilities in saving countries. In the same light, efforts by governments to try to control the COVID-19 pandemic's spread whilst managing its wide-ranging impact demonstrate the critical role of the state and state institutions in shaping the effectiveness of government responses, strategies and approaches in tackling the crisis. Mechanisms that have been implemented to mitigate the spread of the disease in these countries have mainly been centrally directed and include lockdowns, closing borders, cutting off flights, shuttering schools and universities, encouraging or requiring physical separation or sheltering in place, social distancing, contact tracing, work from home orders and ordering the closure of businesses and even entire industries.

However, despite this array of measures, critiques have argued that the measures have been way too centralised and not sustainable (Altman 2020). Their argument is that to be effective, measures in this context should increase the balance between health and economic imperatives through adopting an approach that enables participation and compliance in health solutions by communities, workers and businesses as well. It will therefore be important to trace the trajectory of these measures over time. In both countries, the full health and economic effects of both the pandemic and government responses are not yet fully known.
This research study will support knowledge generation through analysing the state and its institutions for leadership and action in Botswana and South Africa with specific emphasis on how the governments have responded to the health and economic challenges posed by COVID-19 and the consequences thereof. This will provide lessons for future interventions in similar circumstances.

When the virus began to spread, predictions about Africa and this virus were riddled with assumptions of likely complete failure to respond appropriately to the pandemic (Devdispatch 2020). However, the uncertainty regarding the spread of COVID-19 remains high and its impact on Africa's economies remains worrisome. Therefore, by focussing on the response priorities of the COVID-19 pandemic in Africa using the case studies of Botswana and South Africa, this study will contribute to current policy debates especially on the extent to which COVID-19 prevention and control strategies have contributed towards minimising the spread of the virus, balancing this with mitigating the socio-economic impact of the strategies in a parallel and coordinated fashion. The study will also help to inform policymakers seised with the COVID-19 pandemic to better appreciate efforts to control the COVID-19 pandemic's spread whilst managing its wide-ranging economic impacts and demonstrate the critical role of the state and state institutions in shaping the effectiveness of government responses, strategies and approaches in tackling the pandemic.

Furthermore, the study will reveal ways in which government and government institutions in different contexts can respond to the pandemic. In terms of policy, lessons can be drawn from one context, to inform the management of health and economic priorities in the control and prevention of the COVID-19 pandemic. In other words, this study will provide an exposure to the experiences of Botswana and South Africa in managing health and economic priorities in the control and prevention of the COVID-19 pandemic and establish what has worked and what has not.

In that regard, this research is of 'dual imperative', (Jacobsen \& Landau 2003), that is, it informs both policy practitioners and also contributes to existing scholarly debates on the COVID-19 pandemic. The dissemination of the findings from this study will therefore target a variety of audiences. It will target Botswana, South Africa and African governments in general and operational level - on-the-ground decisions and behaviours taken by medical personnel, epidemiologists, emergency managers and other professionals coping with the pandemic's immediate threat.

\section{Methodology}

This study examines Southern African responses to the COVID-19 pandemic with emphasis on the management of health and economic priorities using the case studies of Botswana and South Africa. The case studies of Botswana and South Africa 
invite us to reveal what worked, how it worked, why it worked, challenges they faced and how they overcame them. The study also proposes innovative solutions to cope with challenges posed by the COVID-19. The study uses a qualitative approach. In this regard, the qualitative research approach provides a high degree of flexibility in addressing the research questions. In conducting the study, we primarily focus on two cases studies, namely Botswana and South Africa. The case study strategy allows a detailed exploration and understanding of complex issues (Zainal 2007). In this context, the case study approach provided a vantage point for detailed description and analysis of the responses to the COVID-19 pandemic in the aforementioned countries between March 2020 and September 2020. Document analysis, a form of qualitative research in which documents are interpreted by the researcher to give voice and meaning around a research study, was used (Bowen 2009). Analysing documents involved coding content into themes to draw conclusions. Critical documents were drawn from government institutions, research institutions and general sources.

\section{World Health Organization COVID-19 management guidelines}

The health system provides a dedicated platform from which governments are able to launch efforts to prepare for and respond to disease outbreaks and respond to broader health needs and social issues affecting the well-being of individuals, families and communities. Seen as the social fabric of society (Gilson 2012; World Health Organization [WHO] 2000), the health system performance becomes central to the COVID-19 response. With the onset of the COVID-19 pandemic, the whole world was thrown into a pandemonium. The WHO, whose major function is the attainment by all people of the highest possible level of health cautiously moved in to declare the COVID-19 a global pandemic. Globally, the COVID-19 pandemic has placed immense pressure on national health systems. Experience from relatively wellresourced and high-performing health systems settings indicates that as caseloads increase and the need for hospitalisation increases, the healthcare system quickly becomes overwhelmed (Legido-Quigley et al. 2020). Southern African nations' health system is particularly at higher risk, where past acute disease shocks and chronic stressors have already weakened the health system. This situation is worsened when governments attempt to address the disease outbreak; response efforts often include system re-orientation and resource reallocation that create an unintended imbalance across the health system building blocks especially because response efforts often do not apply systems thinking lens to address the crisis.

Seeking to support member states to prepare for and respond to the COVID-19 pandemic, the WHO has been issuing rapid guidelines that also aim to align with the trajectory of the disease for which much remains unknown. The WHO guidance on restriction of people's movement aims to prevent the introduction of the virus from infected areas to non-infected areas. It is WHO's guidance that national
BOX 1: World Health Organization COVID-19 strategic preparedness and response planning pillars.

P1: Coordination, planning and monitoring
P2: Risk communication and community engagement
P3: Surveillance, rapid response teams and case investigation
P4: Points of entry
P5: National laboratories
P6: Infection prevention and control
P7: Case management
P8: Operational support and logistics.

governments ought to implement taking into consideration the local intensity of COVID-19 transmission, which can be classified into four categories including no cases, sporadic cases, clusters of cases and community transmission. For purposes of this article, we use the WHO interim guidance for COVID-19 Strategic Preparedness and Response Plan (SPRP) ${ }^{1}$ (WHO 2020a) to unpack the various efforts mounted by Botswana and South Africa to prepare for and respond to COVID-19 outbreak. The WHO guidelines aimed to provide a road map for national governments to prepare for and respond to COVID-19 and it outlined eight strategic pillars (Box 1) for priority steps and actions to be included in Country Preparedness and Response Plan (CPRP). These guidelines have been subsequently updated as new information about the disease becomes available. However, the strategic pillars have remained a key framework that has provided a foundational basis upon which current efforts and improvement are built.

As with all other guidance provided by the WHO, the SPRP has been intended for national governments to align them with existing national guidance and plans for dealing with health and public health emergencies to ensure due consideration for country contexts. The guidelines also aimed to help countries to gauge their resource requirements to prepare for and respond to COVID-19 disease outbreak.

How countries used the guidelines to rapidly adapt to the existing national plans and guidelines has been varied but generally took after the WHO strategic pillars. Countries were to develop detailed gap and needs analysis to develop their COVID-19 CPRP and resource requirements to support response measures. The SPRP focusses on the public health measures to support national preparedness and response and does not include the broader measures required to mitigate the social and economic consequences of COVID-19 on individuals, families and communities, including businesses. However, in applying the SPRP and scaling up the public health preparedness and response measures, it was recommended for national governments to develop, in parallel, plans to ensure continuity of essential services and mitigating the social and economic impact of COVID-19.

Djalante et al. (2002:1) posited that on 26 March 2020, the WHO issued six prioritised strategies that were to be undertaken by governments to cope with the pandemic. The strategies were as follows: expand, train and deploy

1.The WHO Operational Planning Guidelines to Support Country Preparedness and Response - Draft as of 12 February 2020. 
healthcare workers; implement systems to find suspected cases; ramp up production of tests and increase availability; identify facilities that can be transformed into coronavirus health centres; develop plans to quarantine cases; and refocus government measures on suppressing the virus. World Health Organization also advised that lowering and delaying the epidemic peak was important. They also cautioned that sporadic and uncontrolled measures would lead to the rapid increase in the number of cases, reach the peak earlier and require more capacity of healthcare systems to respond, whilst stringent control measures implemented early will help to lower the number of cases, delay reaching the peak and need considerably lower capacity of the healthcare systems (Djalante et al. 2002:1).

\section{COVID-19 prevention and control measures in Botswana \\ National governments' responses}

In view of its small population and geographical location (landlocked), Botswana was swift to adopt WHO's prioritised strategies. On 31 March 2020, His Excellency, the president of Botswana, declared a State of Public Emergency (SoE) with effect from midnight on 2 April 2020 for a period of 6 months. The SoE was without controversy and received strong backlash from Opposition Parties who argued that the ruling party is politicising the epidemic and wants to 'rule alone'. A protracted Parliamentary debate that was aired on national television station also attracted public debate and media reports that indicated similar views as raised by members of opposition parties. The days that followed declaration of the SoE were occupied by public discourse in numerous social and print media analysing elements of the epidemic that warranted the ruling party's motion for SoE to deal with COVID-19. One of the central arguments put forward by the ruling party was that there were many that remain unknown about COVID-19 and how countries must prepare for and respond to preventing the spread of the virus and managing those infected. As such, it was important that the government be in a position to make necessary and rapid decisions as new information become available. It was also argued that whilst the Public Health Act allowed Director of Health Services to make necessary policy and regulatory enforcements, he was limited in certain areas including mobilisation of the Armed Forces and regulatory changes affecting the business community. This debate is critical and has played a significant role in shaping and influencing the perception of the general public regarding government's approach to the crisis and its trustworthiness.

\section{National or presidential task force for COVID-19 rapid response}

President Mokgweetsi Masisi established a COVID-19 Task Force Team whose mandate was to advise government on what measures to take to arrest the pandemic. The task team is composed of the Task Team leader Professor Kereng Masupu - a veterinarian and Public Health Independent Consultant, Dr. Mogomotsi Matshaba - A Paediatrician and Assistant Clinical Professor of Paediatrics, Baylor College of Medicine and Deputy Director - Botswana-Baylor Clinic, Professor Mosepele Mosepele - a Senior Lecturer in Internal Medicine or Infectious Diseases in Faculty of Medicine, University of Botswana and Dr. Malaki Tshipayagae - a Surgeon and Director of Health Services in the Ministry of Health and Wellness (Chida 2020). The COVID-19 taskforce was charged with regular COVID-19 updates and announcements of major shifts such as declaring of zonal lockdowns.

\section{Quarantine centres}

Soon after COVID-19 measures were released, on 24 March 2020 a mandatory 14-day quarantine was imposed on all travellers entering the country, expanding the list of high-risk countries that initially included mainly European, America and Asian countries to include neighbouring countries. The national government also moved to close boarders on 24 March 2020. Many travellers arriving at various ports of entry into Botswana from South Africa, Zimbabwe, Zambia, etc. found themselves 'trapped' as this mandatory quarantine was announced and implemented on the same day. It was an act that went against WHO guidance regarding considerations to be given when quarantining individuals in a bid to contain the disease.

The WHO rightly recommended that in order to promote trust, ensure compliance and reduce panic, national governments should ensure clear and timely information sharing regarding such measures (WHO 2020b).

Quarantine facilities were designated within hours and mainly included student accommodations in public tertiary institutions and other government facilities. Pursuant to Regulation 6 of the Emergency Powers (COVID-19) Amendment (No. 4) Regulations, 2020, which empowered the Director of Health Services to require persons liable to be quarantined to pay the costs of their quarantine, as of 05 June 2020 , the following persons were required to bear the costs of quarantine according to the following schedules:

- Returning citizens and residents; $50 \%$ cost of quarantine and $100 \%$ if they opt out of the government-designated quarantine facilities, provided their chosen facility meets COVID-19 guidelines.

- All companies whose employees or other agents return to or enter Botswana will cover $100 \%$ of cost of quarantine.

- Diplomats will be permitted to self-quarantine at home.

- For local contacts of COVID-19 requiring quarantine, the Botswana Government will cover $100 \%$ costs of their quarantine unless they opt out of government-designated quarantine site, provided their chosen facility meets COVID-19 guidelines.

- Undocumented immigrants will be quarantined at police holding sites and swabbed prior to repatriation to their countries.

- In exceptional cases, home quarantine may be permitted provided that such quarantine facility meets COVID-19 guidelines. It should be noticed however that home quarantine will be effective fully once Botswana Government has rolled out tracking and geo-fencing mechanisms. 
However, many of the designated government quarantine centres had problems. Soon these became problematic where the quarantine conditions were found to be unsatisfactory with regard to the WHO recommendations for appropriate quarantine (Box 2) that promotes public health safety, human rights and dignity.

People were reportedly quarantined under conditions, which were not segregated, sanitary or hygienic, with no proper infection control. Facilitated by a prominent Law Firm in the country - daughter of one of the Managing Partners to the firm happening to be amongst the quarantined people - a case was launched before the courts of law to compel the Government of Botswana (GOB) to offer proper quarantine conditions for all.

An order was granted and GOB together with the business community moved to provide proper quarantine facilities, which included accommodation in hotels and lodges around the country at government expense. The types of lodging ranged from five star hotels to Lodges and Bed and Breakfast accommodation depending on place of entry and regional business environment.

Botswana's mandatory quarantine may have well been timely and fundamental in preventing or delaying the introduction of COVID-19 disease in the country, where the three cases that were later to be reported in the country were all imported cases. Local transmission remained very low in country. Furthermore, the country had already put in place four key strategic measures to help prevent the spread and containment of the disease including active surveillance, early detection, case management and contact tracing. However, early in the country's preparedness and response strategy, there was no local testing capacity. The National Laboratory was eventually upgraded and accredited to be able to complete COVID-19 testing. This meant that people who were in quarantine went for a few days before any testing could be carried out for them. The delay was further exacerbated by the fact all probable cases were sent to South Africa for a confirmatory test.

\section{Economic relief measures}

The onset of COVID-19 pandemic and the attendant lockdowns for extreme social distancing brought untold suffering and livelihoods were lost. Whilst countries were battling with the chronic poor and poverty in general, the COVID-19 pandemic exacerbated the creation of another category of the poor termed the newly poor. These are individuals or households who are the direct victims of the crisis of development policy that has rendered them unemployed. They may include retrenched workers and civil servants. Hanley (2002), for example, noticed the importance and implications of the disaggregation of categories of the poor for policy development and implementation (Hope 2004).

The GOB availed funds to local authorities to acquire and distribute food relief packages to the vulnerable under psycho-social support. Social workers went round the communities compiling lists of all the needy cases. The cases were to be assessed and consolidated and distribution effected. There were two different packages of food items. The 1st Package was to cater for a family of 1-5 people and the 2 nd package was for a family of 6-10 people. There was also a wage subsidy given to employers to be able to pay half salaries or a maximum of P2500 per employee. This wage subsidy also buttressed government's effort and regulation that no employee would be retrenched or lose his job during the period of the lockdown.

As a way of kick-starting or sustaining business activities the GOB undertook to give businesses some cash-flow relief. This was performed in the following ways:

- Guarantee loans by commercial banks to businesses mostly affected by COVID-19.

- Give eligible businesses affected by COVID-19 access to credit to support ongoing operations in conditions where credit becomes more difficult to obtain.

- Give tax concessions to businesses in eligible sectors.

- The Ministry of Finance and Economic Development will provide more details on the criteria and guidelines for implementation of these particular measures.

- Furthermore, to facilitate doing business and keep the economy running.

BOX 2: World Health Organization recommendations for appropriate quarantine arrangements.

- Those in quarantine be placed in adequately ventilated, spacious single rooms, with en-suite toilet (hand hygiene and toilet facilities). If single rooms are not available, beds
should be placed at least $1 \mathrm{~m}$ apart.
- Suitable environmental infection controls, such as adequate air ventilation, filtration systems and waste-management protocols.
- Maintenance of social distancing (more than $1 \mathrm{~m}$ ) of the persons quarantined.
- Accommodation with an appropriate level of comfort, including, food, water and hygiene provisions.
- Protection for baggage and other possessions.
- Appropriate medical treatment for existing conditions.
- Communication in a language that they can understand explaining, their rights, provisions that will be made available to them, how long they will need to stay; what will happen
- Assistance for quarantined travellers, isolated or subject to medical examinations or other procedures for public health purposes.
- Assistance with communication with family members outside the quarantine facility.
- If possible, access to the internet, news and entertainment.
- Psycho-social support; and special considerations for older individuals and individuals with co-morbid conditions, because of their increased risk for severe coviD-19 disease.

Source: World Health Organization (WHO), 2020a, Considerations for quarantine of individuals in the context of containment of cornavirus disease (COVID-19), World Health Organization, Geneva. $\mathrm{m}$, metre; COVID-19, coronavirus disease 2019. 
TABLE 1: Summary of Botswana's COVID-19 economic response interventions.

\begin{tabular}{|c|c|c|c|c|}
\hline Number & Description & Summary of components & Key guidelines & Implementation \\
\hline $\begin{array}{l}\text { Objective 1: Support } \\
\text { to workers }\end{array}$ & $\begin{array}{l}\text { Aimed at ensuring or } \\
\text { assisting businesses to } \\
\text { retain workers }\end{array}$ & $\begin{array}{l}\text { - Wage subsidy for a period of } \\
3 \text { months } \\
\text { - Business must be registered with } \\
\text { Botswana Unified Revenue } \\
\text { Services (BURS) } \\
\text { - Assistance offered regardless of } \\
\text { whether the business owed tax }\end{array}$ & $\begin{array}{l}\text { - Wage subsidy targeted adversely affected } \\
\text { businesses }{ }^{1} \\
\text { - Businesses benefiting from the subsidy should not } \\
\text { retrench employees } \\
\text { - Parastatals and businesses with direct government } \\
\text { shareholdings are excluded }\end{array}$ & $\begin{array}{l}\text { - Fully implemented with most } \\
\text { over } 90 \% \text { of businesses that } \\
\text { applied for the wages receiving } \\
\text { them for the month of April. } \\
\text { - Fewer businesses have } \\
\text { received payments for May } \\
\text { and June }\end{array}$ \\
\hline $\begin{array}{l}\text { Objective } 2 \text { : Stabilise } \\
\text { businesses }\end{array}$ & $\begin{array}{l}\text { Aimed at private sector } \\
\text { businesses }\end{array}$ & $\begin{array}{l}\text { - Government loan guarantee up } \\
\text { to } 1 \text { billion } \\
\text { - Tax concessions } \\
\text { - Various monetary policy } \\
\text { measures }\end{array}$ & $\begin{array}{l}\text { - Business must be tax compliant } \\
\text { - Cover of guarantee } 24 \text { months } \\
\text { - Maximum loan per borrower P } 25 \text { million } \\
\text { - BURS to allow deferral of } 75 \% \text { of any two quarterly } \\
\text { payments between March and September } 2020 \\
\text { - Reduce VAT refunds from } 60 \text { to } 21 \text { days } \\
\text { - Businesses with turnover over } 25 \text { million per } \\
\text { annum to negotiate on a case-by-case } \\
\text { - Reduce bank rates, restructuring loans to extend } \\
\text { payment periods, etc. } \\
\text { - Ease of doing business }\end{array}$ & - Fully implemented \\
\hline $\begin{array}{l}\text { Objective 3: Ensuring } \\
\text { availability of strategic } \\
\text { reserves }\end{array}$ & $\begin{array}{l}\text { To provide funding for } \\
\text { strategic reserves and } \\
\text { other costs }\end{array}$ & $\begin{array}{l}\text { - Grain reserves } \\
\text { - Medical emergency supplies } \\
\text { - Water supply } \\
\text { - Psychosocial support }\end{array}$ & $\begin{array}{l}\text { - Administered through the ministry of local } \\
\text { government and rural development }\end{array}$ & - Fully implemented \\
\hline $\begin{array}{l}\text { Objective 4: Promoting } \\
\text { opportunities } \\
\text { for economic } \\
\text { diversification }\end{array}$ & $\begin{array}{l}\text { To provide local } \\
\text { production of goods and } \\
\text { food item in the context } \\
\text { of COVID-19 }\end{array}$ & $\begin{array}{l}\text { - Economic stimulus package } \\
\text { - Promote market centres for } \\
\text { agricultural products } \\
\text { - Promote livestock value chain, etc. }\end{array}$ & - & - \\
\hline
\end{tabular}

Source: Mazars, 2020, Botswana government's economic interventions in response to COVID-19, viewed 14 August 2021, from https://www.mazars.co.bw/content/download/991548/51835020/ version/file/Summary_of_the_COVID_19_Speech_Finance_Ministetr.pdf.

COVID-19, Coronavirus disease 2019; VAT, Value Added Tax; BURS, Botswana Unified Revenue Services.

All government institutions will pay Government Purchase Orders (GPOs) within 5 days and parastatals will pay within $24 \mathrm{~h}$ :

- The efficiency of procurement processes will be improved.

- Government will pay all outstanding arrears for invoices within 2 weeks and extended the validity period for GPOs.

- VAT refunds to businesses will be expedited to assist with cash flow.

- In the financial services industry.

- Banks have agreed to offer restructuring of loan facilities through which each bank will consider each case within their credit policy and parameters. This will include owner-occupied residential property mortgages and motor vehicle loans.

- All commercial banks will offer a payment holiday for 3 months with the option to extend to 6 months to the affected sectors.

- Regular payment obligations including life insurance premium payment, retirement fund contributions and loan instalments will be restructured and rescheduled to offer relief for at least 3 months to COVID-19 affected people subject to individual policies.

(See GOB COVID-19 portal https://covid19portal.gov.bw/ assistance-businesses).

In addition to these measures, the GOB established the COVID-19 Relief Fund and put up an investment of 2 billion Pula as seed money into it (COVID-19 portal). Individuals and the private sector were encouraged to contribute to this fund, the latter, as part of their social responsibility. Accounts were opened at First National Bank, Standard Chartered, Absa, Stanbic, Bank Gaborone, First Capital Bank, BancABC, Bank of Baroda and Bank of Botswana. Table 1 presents a summary of Botswana's COVID-19 Economic Response Interventions.

The Botswana Investment and Trade Centre (2020) argued that the country's:

[E]conomic response to the COVID-19 has been ranked in the top 10 responders to COVID-19 economic challenges ranking after Egypt and most specifically, commended for the Government wage subsidy initiative. (p. 4)

Overall, in June 2020, Botswana launched a survey to assess public perception of its response to the COVID-19 pandemic. It argued that its measures had been successful in curbing the pandemic (APA News 2020).

\section{COVID-19 prevention and control measures in South Africa National governments' responses}

On March 5, South Africa reported the first confirmed COVID-19 case. This was a 38-year-old man who was part of a group of 10 people who returned from a trip to northern Italy a few days earlier. South Africa announced a national lockdown on 26 March 2020, having recorded 402 confirmed COVID-19 cases (Msomi \& Pilane 2020). The president of the Republic, Cyril Ramaphosa declared a national state of disaster and called for measures to combat the spread of the pandemic. Since the first lockdown announcement, the spread of COVID-19 in South Africa has been massive (National Institute for Communicable Diseases 2020). This section presents key responses by the South African government beginning with an analysis of regulatory and institutional frameworks for health emergency responses.

2.These included business in travel and tourism sector, export-oriented enterprises SMEs and other sectors of the economy whose employees became unemployed because of nation-wide lockdown 


\section{Regulatory and institutional responses by national government}

In response to the COVID-19 pandemic, numerous national regulations were produced by the government at different levels from the president to ministerial levels. A number of regulations and rules were also produced to guide national and local responses. Dr. Nkosazana Dlamini Zuma, Minister of Cooperative Governance and Traditional Affairs, as designated under Section 3 of the Disaster Management Act, 2002 (Act No. 57 of 2002), declared a national state of disaster on 15 March. This was after recognising that special circumstances existed to warrant the declaration of a national state of disaster. In terms of Section 27(2) of the Act government may, when required, make regulations or issue directions or authorise the issue of directions for the purpose of: (1) assisting and protecting the public, (2) providing relief to the public, (3) protecting property (4) preventing or combating disruption or (5) dealing with the destructive and other effects of the disaster.

On 16 March, the country went into a total lockdown. Five alert levels were established. Level five was the most drastic and involved a complete lockdown. This required all South Africans to stay at home except for individuals performing essential services, those procuring essential good or receiving an essential service, collecting a social grant or seeking emergency, life-saving or chronic medical attention. These regulations also restricted international travel, prohibited gatherings of more than 100 people, closed schools and other educational institutions and restricted the sale of alcohol and cigarettes amongst other actions. Further regulations were promulgated through the government gazette on 16 April 2020. These regulations included: (1) banning of visits to correctional centres, (2) remand detention facilities, (3) holding cells, (4) military detention facilities and (5) Department of Social Development facilities, including Child and Youth Care Centres, shelters, One Stop Centres and Treatment Centres amongst other places.

Level four regulations were imposed from 01 to 30 May 2020. In terms of the level four regulations, people could travel to perform and acquire services only where such services could not be provided from the safety of their homes. Permitted business sectors were advised to take into account the necessary social distancing guidelines as per the National Department of Health. The president argued that the process engaged at the two levels was meant to delay the spread of the virus and give the country time to prepare health facilities and mobilise some of the essential medical supplies needed to meet the inevitable increase in infections. Similar conditions applied at level three but additional businesses such as domestic air travel, schools and essential government services were allowed to operate. Level two saw the permission of interprovincial travels and restricted opening of more industries. Progression was meant to ensure that the pandemic is reduced to negligible levels if not eliminated.

\section{National coronavirus command council for COVID-19 rapid response}

On 15 March, the state president announced the establishment of a National Coronavirus Command Council (NCCC) 'to coordinate all aspects of our extraordinary emergency response' to the COVID-19 crisis. All government departments issued guidelines for services within their jurisdictions. Most of these regulations were issued after government established the NCCC. The NCCC, made up of 20 of the 33 Ministers and their director generals, emerged as central cog in South Africa's response to the pandemic (Singh 2020). The prominence of the members of this facilitated information dissemination, drawing of lessons and experiences from other parts of the world and generated a better understanding of the nature of the pandemic, its challenges and myths. The NCCC is a Cabinet committee, which was set up to deal with the COVID-19 pandemic in the country is accountable to Parliament for the decisions it made. The National Join Operational and Intelligence Structure (NatJOINTS) composed of the country's security and law enforcement operations roped in to coordinate government's daily response to COVID-19.

The NCCC is supported by a Ministerial Advisory Committee (MAC), composed of 45 eminent scientists with expertise and experience in laboratory testing, clinical matters, public health and research (Wiysonge 2020). The role of these professionals emphasised on science and evidence-based planning. Thus, South Africa's response to COVID-19 benefited from these professional and scientific advisers with high expertise.

Creation of both the NCCC and the MAC resulted in aggressive sound domestically tailored and scientifically and culturally sound public health actions that emphasised preventive interventions, rather than a therapeutic approach in order to prevent the overwhelming limitations posed by limited treatment options at hospitals. The NCC became the centre of decision making in the government's response to COVID-19 as the country dealt with the consequences of the pandemic. Meetings of the NCCC at the peak of the pandemic would last anywhere between $3 \mathrm{~h}$ and $6 \mathrm{~h}$ (Hunter 2020). However, critics such as Hunter (2020) had argued that most of these meetings were performed secretly and information on how the Council arrived at most decisions was never made public. Furthermore, this led to some sections of society challenging its decisions in the public, legislature and in the courts of law.

\section{Quarantine centres and isolation}

The Department of Health (2020) published guidelines for quarantine and isolation in relation to COVID-19 exposure and infection. According to the guidelines, quarantine is for people who are asymptomatic, but who may be infected with COVID-19. The quarantined are kept away from others to prevent them from potentially and unknowingly infecting anyone. Individuals under such circumstances are kept in quarantine facilities. According to the guidelines, although 
isolation serves the same purpose as quarantine, it is carried out in the case of those who are already sick and or have tested positive for COVID-19 infections, but do not require hospital admission for medical care. However, both isolation and quarantine were meant to prevent people from potentially and unknowingly infecting others. In terms of facilities, in both instances, the guidelines allow people either to quarantine at home (self-quarantine) or at a facility (administered quarantine).

Firstly, the period for quarantine or isolation for asymptomatic patients was pegged at 10 days starting on the day 1 tested positive. Secondly, in the case of a mild disease it was set at 10 days from onset of symptoms. Thirdly, moderate or severe disease was set at 10 days following clinical stabilisation, that is, when the person no longer requires oxygen. The original period was 14 days but was reduced to 10 days in line with the revised WHO guidelines that South Africa should implement its own quarantine or isolation guidelines.

The government established state-sponsored provincial level quarantine and isolation facilities for those unable to separate themselves at home. Such facilities were established at hotels, resorts, university or college buildings, etc. and those in need of such will be transported to the centres at government cost. An important requirement was that a nurse should be present at the facility for at least $8 \mathrm{~h}$ a day to administer daily temperature checks and assist with any other healthcare needs that may arise. The Department of Health identifies 521 quarantine facilities across the country.

Regarding enforcement for self-quarantine or isolation, if a person fails to self-quarantine or self-isolate according to the guidelines, an enforcement officer (police or military) was mandated by the policy to legally enforce the person to a mandatory isolation or quarantine facility.

Although the threat of an unprecedented public health crisis such as COVID-19 may occur and call for extraordinary containment measures, such as isolation and quarantine, either on a voluntary basis or enforced, conflicts do sometimes arise around ethics, human rights and the law. Moodley and Obasa (2020) posited that South Africa had to minimise the infringement of civil liberties when implementing isolations and quarantines.

In this regard, to an extent, South Africa seems to have achieved some fair measure of compassion, restraint and respect for human rights.

\section{Enforcement mechanisms through government departments}

As soon as the state of disaster was declared, the Minister of health, Dr. Zweli Mkhize took a lead in providing daily statistics regarding the spread of the virus in all provinces. The minister has worked with a National Health Council and all the provincial Members of Executive Councils (MECs) and Heads of Departments (HODs) for Health. The purpose of the meetings was to discuss the latest situational analysis of each province as more COVID-19 cases were being confirmed. The minister also held numerous meetings with other stakeholders.

In addition a MAC on COVID-19 was established with subcommittees that included pathologists and laboratory sub-committee, a clinicians sub-group, the public health subcommittee and a research sub-committee with Glenda Gray as the chair.

The MAC submitted a number of recommendations including advisories on community surveillance, rapid test kits, isolation and household quarantine. The committee also submitted an advisory on the public use of cloth masks. This advisory outlined the rationale for the general use of cloth masks as a supporting strategy to curbing the spread of the coronavirus. Advisories currently in the pipeline include safely reopening schools, using saliva for testing the virus and how to ease lockdown.

The Minister of Health also provided case management in the context of a South African COVID-19. Case management involved providing information on the various ways in which transmission takes place, what measures can be taken to prevent the transmission of the virus and how to manage infections.

In addition, South Africa's army, police and provincial police were deployed to help enforce curfews and lockdown rules. Unfortunately, however there were concerns of 'militarisation' of policing. Militarisation refers to situations whereby the uniformed forces adopt a combative culture of militaries and pursue aggressive tactics of law enforcement, as well as the increasing use of soldiers in policing roles. Mitton (2020) posited that subsequently media reported violent confrontations, especially between police and residents in townships. Furthermore, videos of harsh punishments by soldiers and police went viral on social media, leading the UN to express concern over the enforcement of social distancing with rubber bullets, tear gas and whips.

\section{Economic relief measures}

Further to the regulations, the president announced a series of socio-economic relief measures meant to support both business and the vulnerable and poor citizens. The UNDP (2020) said that in South Africa, like in many other countries, the country's Gross Domestic Product (GDP) will take a knock and would take least 5 years to recover from COVID-19 impact. The report by the United Nations Development Program (UNDP) also revealed that COVID-19 impact, included major setbacks in addressing poverty, unemployment and inequality. Furthermore, the number of households below the poverty line increased as households fell from the lower middle class with many households pushed out of jobs whilst many households would exit the middle class into vulnerability. Populations hit especially hard included the alreadyimpoverished female-headed households, persons with only primary education, persons without social assistance, black 
populations and heads of households who have been pushed from permanent to informal employment. In response to these negative consequences of COVID-19, the government announced a series of measures to curb the economic impact.

In April 2020, the government announced a R500 billion social and economic stimulus package understood to be the biggest ever once-off stimulus injection in South African history (Schneidman, McLaren \& Taylor 2020). The economic stimulus was apportioned to different areas. Roughly R20 billion was dedicated to fighting amongst other things, community screening, testing and personal protective equipment for health workers. A total of R50 billion was in grants directed towards addressing the needs of those most desperately affected by the pandemic, with child-support grant beneficiaries receiving extra R300 in May and a further R500 per month from June to October 2020. All other grant beneficiaries not covered by the R50 billion social grants received an extra R250 per month for the next 6 months beginning in June 2020. Unemployed individuals who did not receive any other forms of grants or Unemployment Insurance Fund (UIF) payments received R350 per month for 6 months.

Beyond social grants, municipalities were awarded R20 billion for the provision of emergency water supplies, increased disinfection of public transport and facilities and food and shelter for the homeless. Approximately R100 billion was set aside to protect existing jobs and creating new jobs. A R200 billion loan guarantee scheme was extended to banks and small businesses (with an annual turnover of less than R300 million) to cushion them from the effects of economic impact of the coronavirus pandemic.

Furthermore, an array of tax relief measures amounting to about R70 billion was extended either in the form of cash flow relief or direct payments to individuals and businesses. The tax relief included a 4-month holiday for companies' skills development levy contributions, fast-tracking of Value Added Tax (VAT) refunds, a 3-month deferral for filing and payment of carbon taxes, an increase in the turnover threshold for tax deferrals for businesses to R100 million per year and increasing the portion of Pay-As-You-Earn (PAYE) payments that may be deferred to $35 \%$. Taxpayers who were exempted were not penalised if they were able to show they were disadvantaged by the coronavirus pandemic, whilst taxpayers who donated towards the Solidarity Fund qualified for a tax rebate of an additional 10\%.

According to Schneidman et al. (2020), in general the broader South African society welcomed the social and economic relief package although it faced implementation difficulties.

\section{Recommendations for health and broader system resilience}

The COVID-19 pandemic is an enormous and complex threat, which requires a deliberate, practical and carefully nurtured multi-sectoral approach and dictates that policymakers, researchers, practitioners, communities and all stakeholders build the systems' capability for implementation of various interventions and effort.

The following recommendations draw from the present synthesis around reported or prevailing challenges documented in Botswana and South Africa:

- Building and managing effective partnerships and coordination mechanisms: To prepare for, manage and effectively recover from any acute disease outbreak requires a multi-sectoral approach that is deliberate and effective. In the case of COVID-19, the need for a multisectoral approach is made more complex as it extends beyond national boarders thereby introducing an element of State control, which often yields tensions within spaces of communication and development paradigms. To help effectively address some of the issues already discussed in this article, health system stewards ${ }^{3}$ (Savigny \& Adams 2009:76) need to create safe spaces for consensus building and creation of shared vision towards collective responses. This requires going beyond the usual rhetoric of a satisfying representativeness of those deemed appropriate to include in critical dialogues, decisions and implementation efforts. Creating safe spaces for inclusion requires that each stakeholder should be clear about the value of their contribution to the task at hand and that processes are clearly outlined to ensure proper coordination and synergy of efforts. The United Nations AIDS (UNAIDS) has also offered lessons from human immunodeficiency virus (HIV) prevention, treatment and care submitting that civil society, community-led organisations, faith-based groups and local leaders can be engaged as co-creators of the COVID-19 response leading the response to reach their communities, especially vulnerable populations thereby ensuring ownership and effectiveness in implementation of prescribed interventions (Global HIV Prevention Working Group 2020).

- Minimise top-down approach to implementation of strategies and other response measures: There is significant evidence showing that top-down approach to policy implementation and addressing complex social issues generally contributes to ineffective translation of policy into practice (Barrett \& Fudge 1981; Gilson et al. 2006; Sabatier \& Mazmanian 1983). The challenges of top-down approach are compounded by communication channels that are available to the public today. Thus policy directives are received in the context of increased information that may be untrue or misrepresented and often affecting public trust of government. The numerous public health measures taken by governments to address the COVID-19 disease outbreak have varied impact on society including a negative impact on people's socioeconomic well-being. National governments should implement collaborative recommendation through a process of top-down or bottom-up perspective to help

3. Health system stewards are typically government officials but may also include other stakeholders, for exale, civil society and the private sector whe include other stakeholders, for exanple, civil society and the private sector where system stewards are viewed as information providers and change agents, linking the general public, consumer groups, civic society, the research community, professional organisations and the government in improving health of the people in a participatory way. 
manage public participation, buy-in, compliance and trust in the implementation of authoritative policy directives during a public crisis. Understanding policy formulation and implementation as an interactive process amongst legislators, policy makers, policy implementers and policy recipients is central to this approach.

- Establish multi-disciplinary technical response teams beyond health: This is especially critical for COVID-19, which has brought to the forefront not just only the need for an effective global health infrastructure but also the need for multi-disciplinary approaches to addressing complex social problems. Preparations for and responses to COVID-19 disease outbreak must be understood in the broader context in which they are taking place, being the social, political, technological and economic environment for population existence. By engaging multi-disciplinary teams in technical and rapid response teams and ensuring that teams bring their disciplinary lenses to framing the problems and solutions, integrating knowledge across and between disciplines and mapping out how things stand in relation to each other, will help to minimise some of the public health measures that have negatively impacted countries socio-economic well-being. Multidisciplinary team engagement should not be performed as an ad hoc as in current cases presented here where experts outside health are only consulted for advisory and separate from the established task force teams.

- Promote a people-centred approach: Implementation science has often suggested that it takes time for an intervention to be successfully implemented at scale, citing a number of barriers including lack of buy-in, lack of resources and other competing factors. The COVID-19 crisis and the observable reactions of citizens in many countries do shed light on implementation - perhaps the urgency that a crisis brings. But most notable during a crisis is the solidarity that people building, relationships that are established as citizens are brought together by a common challenge and therefore recognition for a collective effort. This understanding requires that national government should pay attention to and nurture trusting relationships by promoting a people-centred approach in addressing the public health emergency. Establishing two-way communication platforms, conducting rapid population surveys that can help gather and respond to people's questions and concerns must form part of the strategic responses to crisis. National governments should not create communication channels that are only intended to share information and authoritative updates or messages, but rather, communication platforms must promote citizen participation and engagement. Communication should show sensitivity to the concerns and needs raised by the population.

- Build on and strengthen existing structures: Establishing a dedicated task force to help coordinate and drive a country's efforts during a public crisis is critical and can be an effective way of marshalling targeted efforts to deal with an identified problem. However, task forces and working groups should be established and coordinated in consideration of existing leadership and management structures. It is vital that these temporary committees do not become another 'arm' of government, especially the various current Presidential Task Forces and their mandate should seamlessly align with relevant ministries to which they must remain as advisories and not an extension of government powers to centralise authority and decision-making.

\section{Conclusion}

To ensure that African countries and indeed the world in general navigate the challenges posed by the pandemic, the WHO developed operational planning guidelines that have sought to balance the demands of responding effectively to COVID-19 and the need to serve economies from collapse. Southern African countries such as Botswana and South Africa have adopted diverse responses to the challenge it poses to the health and economic sectors. However, an analysis of the programmes of responses in these countries shows the 'domestication' of responses; thus, there is no onesize-fits-all approach to managing cases and outbreaks of diseases such as the COVID-19. However, the domesticated cases, although having met with criticism in some cases have significantly contributed to the effective management of COVID-19 health and economic effects.

\section{Acknowledgements Competing interests}

The authors declare that they have no financial or personal relationships that may have inappropriately influenced them in writing this article.

\section{Authors' contributions}

T.M., D.M., D.M. and A.M. have contributed equally to this article.

\section{Ethical considerations}

This article followed all ethical standards for carrying out research without direct contact with human or animal subjects.

\section{Funding information}

This research received no specific grant from any funding agency in the public, commercial or not-for-profit sectors.

\section{Data availability}

The authors confirm that the data supporting the findings of this study are available within the article.

\section{Disclaimer}

The views and opinions expressed in this article are those of the authors and do not necessarily reflect the official policy or position of any affiliated agency of the authors. 


\section{References}

Altman, M., 2020, 'Smart thinking, lockdown and COVID-19: Implications for public policy', Journal of Behavioral Economics for Policy, Society for the Advancement of Behavioral Economics, 4(S), 23-33.

APA News, 2020, Botswana assesses impact of COVID-19 measures, 19 June, 2020, viewed 13 September 2021, from http://www.apanews.net/en/news/botswanaassesses-impact-of-covid-19-measures.

Barrett, S. \& Fudge, C., 1981, Policy and action: Essays on the implementation of public policy, Methuen, London.

Botswana Investment and Trade Centre, 2020, Government - COVID-19 economic responses, Botswana Investment and Trade, Gaborone.

Bowen, G.A., 2009, 'Document analysis as a qualitative research method', Qualitative Research Journal 9(2), 27-40. https://doi.org/10.3316/QRJ0902027

Chida, D., 2020, 'Meet the all men COVID-19 task force team', The Voice, 21 April 2020 viewed 21 September 2020, from https://news.thevoicebw.com/meet-the-allmen-covid-19-task-force-team/.

Department of Health, 2020, Prevent COVID-19: Policies \& quidelines, viewed 17 September 2020, from http://health.gov.za/covid19/downloads.html?type=policies.

Devdispatch, 2020, Africa day 2020 marks 100 Days since the COVID-19 outbreak: A celebration of a continent not backing down, viewed 13 September 2020, from celebration of a continent not backing down, viewed 13 September 2020, from the-covid-19-outbreak-a-celebration-of-a-continent-not-backing-down/.

Djalante, R., Lassa, J., Setiamarga, D., Sudjatma, A., Indrawan, M., Haryanto, B. et al. 2002, 'Review and analysis of current responses to COVID-19 in Indonesia: Period of January to March 2020', Progress in Disaster Science 6, 10091. https://doi. org/10.1016/j.pdisas.2020.100091

Gilson, L., 2012, Health policy and systems research: A methodology reader, World Health Organization, Geneva.

Gilson, L., Erasmus, E., Kamuzora, P., Mathews, V., Ngulube, T. \& Scott, V., 2006, 'Applying policy analysis in tackling health-equity related implementation gap', in Regional network for equity in health in east and southern Africa, Equinet, Discussion Paper No. 28. viewed 31 September 2020, from https://www. equinetafrica.org/sites/default/files/uploads/documents/DIS28POLgilson.pdf.

Global HIV Prevention Working Group, 2020, Lessons from HIV prevention for prevention COVID-19 in low- and middle-income countries, viewed 12 August 2020, from https://www.unaids.org/sites/default/files/media_asset/lessons-hivprevention-covid19_en.pdf.

Hanley, R., 2002, 'Different times, different places: Histories of infrastructure development', Public Works Management \& Policy 6(3), 170-171. https://doi. org/10.1177/1087724X0263002

Hope, K.R., 2004, 'The poverty dilemma in Africa', Progress in Development Studies 4(2), 127-141. https://doi.org/10.1191/1464993404ps081oa

Hunter, Q., 2020, What exactly is the National coronavirus command council? viewed 12 August 2020, from https://www.news24.com/news24/southafrica/ news/explainer-what-exactly-is-the-national-coronavirus-command-council20200513.

Jacobsen, K. \& Landau, L.B., 2003, 'The dual imperative in refugee research: Some methodological and ethical considerations in social science research on forced methodological and ethical considerations in social science research on forced
migration', Disasters 27(3), 185-206. https://doi.org/10.1111/1467-7717.00228

Legido-Quigley, H., Asgari, N., Teo, Y.Y., Leung, G.M., Oshitani, H., Fukuda, K. et al., 2020, 'Are high-performing health systems resilient against the COVID-19 pandemic?', The Lancet 395(10227), 848-850. https://doi.org/10.1016/S0140-6736(20)30551-1
Mazars, 2020, Botswana government's economic interventions in response to COVID-19, viewed 14 August 2021, from https://www.mazars.co.bw/content/ download/991548/51835020/version/file/Summary_of_the_COVID_19_ download/991548/5183502

Mitton, K., 2020, South Africa's strict pandemic response could give criminal gangs an unexpected boost, viewed 10 July 2020, from https://www.washingtonpost.com/ politics/2020/05/29/south-africas-strict-pandemic-response-could-give-criminalgangs-an-unexpected-boost/.

Moodley, K. \& Obasa, A.E., 2020, 'Isolation and quarantine in South Africa during COVID-19: Draconian measures or proportional response?', South African Medical Journal 110(6), 456-457. https://doi.org/10.7196/samj.2020v110i6.14842

Msomi, N. \& Pilane, P., 2020, LockdownSA: Ramaphosa announces SA lockdown to curb COVID-19 spread, viewed 17 July 2020, from https://health-e.org. za/2020/03/23/lockdownsa-ramaphosa-announces-sa-lockdown-to-curb-covid19-spread/.

National Institute for Communicable Diseases, 2020, Latest confirmed cases of COVID-19 in South Africa, viewed 14 September 2020, from https://www.nicd. ac.za/latest-confirmed-cases-of-covid-19-in-south-africa-7-sept-2020/.

Sabatier, P. \& Mazmanian, D., 1983, 'Policy implementation', in S. Nagel (ed.), Encyclopedia of policy studies, pp. 143-169, Marcel Dekker, New York, NY.

Savigny, D. \& Adams, T., 2009, Systems thinking for health systems strengthening, Alliance for Health Policy and Systems Research WHO, Geneva.

Schneidman, W, McLaren, M. \& Taylor, C., 2020, South Africa's economic response to the COVID-19 pandemic (Part III), viewed 21 July 2020, from https://www.lexology.com/library/detail.aspx?g=7b160336-066a-4214-adac$476 f 443 \mathrm{ac5} 14$.

Singh, J.A., 2020, 'How South Africa's Ministerial advisory committee on COVID-19 can be optimised', South African Medical Journal 110(6), 439-442. https://doi.org/ 10.7196/SAMJ.2020v110i5.14820

Statistics Botswana, 2015, Population and housing census 2011, viewed 05 June 2020 from http://www.statsbots.org.bw/sites/default/files/publications/national statisticsreport.pdf.

Statistics SA (Stats SA), 2020, SA population reaches 58.8 million, viewed 07 June 2020, from http://www.statssa.gov.za/?p=12362.

United Nations Development Programme (UNDP), 2020, Socioeconomic impact assessment United Nations in South Africa, United Nations Development Programme, Pretoria.

United Nations, 2020, A UN framework for the immediate socio-economic response to COVID-19, viewed 07 June 2020, from https://unsdg.un.org/resources/unframework-immediate-socio-economic-response-covid-19.

Wiysonge, C.S., 2020, South Africa's war on COVID-19, viewed 21 July 2020, from https://www.samrc.ac.za/news/south-africas-war-covid-19.

World Health Organization (WHO), 2000, The world health report 2000 - Health systems: Improving performance, World Health Organization, Geneva.

World Health Organization (WHO), 2020a, Considerations for quarantine of individuals in the context of containment of cornavirus disease (COVID-19), World Health Organization, Geneva.

World Health Organization (WHO), 2020b, COVID-19 strategic preparedness and response plan - Operational planning guidelines to support country preparedness and response, World Health Organization, Geneva.

Worldometer, 2020, Botswana - Corona virus cases, viewed 14 September 2020, from https://www.worldometers.info/coronavirus/country/botswana/.

Zainal, Z., 2007, 'Case study as a research method', Jurnal Kemanusiaan Bil 9(6), 1-6. 